\title{
Effects of different preservation temperatures and periods menisci cellularity in rabbits ${ }^{1}$
}

\section{Efeitos de diferentes temperaturas e períodos de preservação na celularidade de meniscos em coelhos}

\author{
Leandro José Reckers², Djalma José Fagundes ${ }^{3}$, Moisés Cohen ${ }^{4}$, José Luiz Pozzo Raymundo ${ }^{5}$ Márcia Bento Moreira ${ }^{6}$, \\ Vanessa Carla Paiva ${ }^{7}$ \\ 1. Research from Surgery and Experimentation Post-Graduate Program of São Paulo Federal University/Escola Paulista de Medicina. - São \\ Paulo - Brazil. \\ 2. Post-Graduated. Doctorate Degree. \\ 3. PhD - Department of Surgery, São Paulo Federal University - SP - Brazil. \\ 4. PhD - Department of Orthopedics, São Paulo Federal University-SP - Brazil. \\ 5. PhD - Department of Orthopedics, Pelotas Federal University -RS - Brazil. \\ 6. Veterinary from Surgery and Experimentation Post-Graduate Program, São Paulo Federal University - SP - Brazil.
}

\begin{abstract}
Purpose: Quantify the progressive decrease of the cellular viability of rabbit meniscus preserved for transplants over a 30 day period at different freezing temperatures. Methods: 180 menisci were removed from 45 rabbits. Menisci were frozen from 2 to 30 days at $-7.2^{\circ}$ Celsius $-21.4^{\circ} \mathrm{Celsius}$ and $-73^{\circ} \mathrm{Celsius}$. Four menisci from each temperature were thawed every two days and the number of present cells was quantified.

Results: On the 14 th freezing day at $-7.2^{\circ}$ Celsius, there were $92.38 \%$ mean viable cells. However, as from the $16^{\text {th }}$ day, there has been a significant $12 \%$ decrease $(\mathrm{p}=0.001)$, as compared to $14^{\text {th }}$ day mean. Mean cell viability at $-21.4^{\circ} \mathrm{Celsius}$ and $73^{\circ}$ Celsius, until the $16^{\text {th }}$ day was statistically similar. As from the $18^{\text {th }}$ day at $-21.4^{\circ}$ Celsius, there has been significant cell count decrease $(\mathrm{p}<0.001)$, especially from the $28^{\text {th }}(54.5 \%)$ to the $30^{\text {th }}(30 \%)$ freezing day. The number of viable cells at -73 ${ }^{0}$ Celsius has shown insignificant $2.3 \%$ decrease $(p=1.000)$ from the $28^{\text {th }}(40.2 \%)$ to the $30^{\text {th }}(37.9 \%)$ day. Conclusion: The amount of viable meniscus cells is similar up to the $14^{\text {th }}$ day of preservation, under any of the used temperatures. However, from the $14^{\text {th }}$ day to the $30^{\text {th }}$ day, the amount of viable cells is smaller in lower temperatures.
\end{abstract}

Key words: Freezing. Meniscus. Transplantation. Rabbits.

\section{RESUMO}

Objetivo: Quantificar a diminuição progressiva da viabilidade celular de meniscos de coelhos preservados para transplantes durante trinta dias em três temperaturas diferentes de congelamento. Métodos: Retirou-se 180 meniscos de 45 coelhos. Os meniscos foram congelados, de dois até trinta dias, a $-7,2^{\circ}$ Celsius $-21,4^{\circ}$ Celsius e $-73^{\circ}$ Celsius. A cada dois dias, de cada temperatura, foram descongelados quatro meniscos e quantificou-se o número de células presentes. Resultados: No $14^{\circ}$ dia de congelamento a $-7,2^{\circ}$ Celsius, a média de células viáveis foi de $92,38 \%$. Entretanto, a partir do $16^{\circ}$ dia observou-se uma redução significante de $12 \%$ ( $\mathrm{p}=0,001$ ), comparando-se com a média no $14^{\circ}$ dia. A média da viabilidade celular, nas temperaturas $-21,4^{\circ}$ Celsius e $-73^{\circ}$ Celsius, até $16^{\circ}$ dia apresentou comportamento estatisticamente semelhante. A partir do $18^{\circ}$ dia na temperatura de $-21,4^{\circ}$ Celsius a redução do número de células foi significante $(\mathrm{p}<0,001)$, especialmente do $28^{\circ}$ (54,5\%) para o $30^{\circ}$ dia (30\%) de congelamento. O número de células viáveis a $-73^{\circ}$ Celsius mostrou uma redução não significante $(\mathrm{p}=1,000)$ de $2,3 \%$ no número de células viáveis do $28^{\circ}(40,2 \%)$ ao $30^{\circ}$ dia $(37,9 \%)$. Conclusão: A quantidade de células de meniscos viáveis é semelhante até o décimo quarto dia de preservação, em qualquer das três temperaturas testadas. No entanto, à partir deste período até o trigésimo dia a quantidade de células viáveis é menor nas temperaturas mais baixas.

Descritores: Congelamento. Meniscos. Transplante. Coelhos.

\section{Introduction}

Meniscal injuries, regardless of type, duration, physical activity or age, have been traditionally treated by total or partial removal ${ }^{1,2}$. In the impossibility of treating injured meniscus, and/or when its removal is imperative, the options are meniscal transplantation or meniscal prosthesis, still in the experimental stage $e^{2,3,4}$. A recent review has shown $86 \%$ to $91 \%$ satisfactory results in patients submitted to meniscal transplantation after meniscectomy ${ }^{5}$. Nevertheless, there is no consensus on the influence of transplanted meniscus cellularity - direct consequence of preservation - on final outcomes. Different preservation techniques and storage periods have different effects on tissue biological and 
biochemical integrity ${ }^{5,6,7}$. Current menisci storage and preservation techniques are similar to other connective tissues and include: fresh method, fresh freezing, dry freezing and cryopreservation ${ }^{7,8,9,10,11,12}$. There are references in the literature on cell viability during frozen preservation of bones, ligaments and tendons ${ }^{13,14}$. A review of the subject could not find reports on frozen preservation of the meniscus itself. A cell viability study would provide more adequate guidance for the optimal moment to perform meniscal transplantations, both for those advocating the need for viable meniscal cells (frozen at minus $4^{0}$ Celsius), and those advocating cell death (frozen as from minus $70^{\circ}$ Celsius). So, our research aimed at evaluating the effects of three different freezing temperatures on meniscal cellularity of rabbits.

\section{Methods}

The experiment was evaluated and approved by the Research Ethics Committee, Universidade Federal de São Paulo - UNIFESP - EPM, protocol 0787/04 and involved 45 male albino rabbits (Oryctolagus cuniculus,New Zealand strain), aged 6 to 8 months, mean weight 3250 grams, from which 180 meniscuses were aseptically collected (90 medial and 90 lateral). Specimens were randomly distributed in three groups: G I - Stored at minus $7.2^{\circ}$ Celsius $(n=60)$; G II stored at minus $21.4^{\circ}$ Celsius ( $\left.n=60\right)$; G III - stored at minus $73^{\circ}$ Celsius $(n=60)$. Four specimens of each study group were sent for histological study every two days, from the $2^{\text {nd }}$ to the $30^{\text {th }}$ day.

\section{Anesthetic procedure}

Animals were premedicated with intramuscular 2.4 mg. $\mathrm{Kg}^{-1}$ acepromazine $1 \%$ and $4 \mathrm{mg} \cdot \mathrm{Kg}^{-1}$ xilazine hydrochloride $2 \%$ in the same syringe (posterior thigh semitendinous and semimembranosus muscles). Marginal auricular vein was used for $0.9 \%$ saline infusion, in addition to $0.5 \mathrm{~mL}$ of anesthetic induction drugs (1:1 ketamine and xilazine). Animals were intubated with $2.5 \mathrm{~F}$ tracheal tube without cuff. Anesthesia was maintained with 1.5\% isoflurane in $2 \mathrm{~L} / \mathrm{min}$ constant flow with respiratory rate of 10 movements/min.

\section{Surgical procedure}

After tricotomy, procedure was started with anterior longitudinal knee incision of approximately $6 \mathrm{~cm}$; subcutaneous divulsion to expose medial articular capsule; and lateral patellar luxation. Mild valgus effort and knee flexion were enough to access and remove medial meniscus; total lateral meniscus removal was performed with varus effort, knee flexion, medial patellar luxation and tibial disinsertion of fibular collateral ligament. Surgery was completed by patellar luxation reduction and articular capsule, subcutaneous and skin suture with polyamide thread 4.0 .

\section{Material colleciton}

Removed medial and lateral menisci were placed in small individual plastic bags sterilized with ethylene oxide, which were then placed in $6 \times 9 \mathrm{~cm}$ plastic jars also sterilized by the same method. Each set was immediately taken to storage in three different temperatures: minus $73^{\circ}$ Celsius, minus $21.4^{\circ}$ Celsius, and minus $7.2^{\circ}$ Celsius.

\section{Microscopic study}

After the freezing period determined for each group, four menisci were removed from their freezers and maintained in room temperature for 20 minutes until complete thawing. Next, they were aseptically removed from their bags and immersed in individual bottles with $10 \%$ formalin, where they remained for 48 hours. Histological processing has included: longitudinal cross-section of the largest meniscus axis, specimens blocking with paraffin, section with rotating microtome adjusted to $4 \mathrm{~mm}$ thickness, preparation of blades and staining with hematoxylin-eosin (HE). Histological description and readings were performed by pathologist blind to the origin of the groups, who has evaluated the following cell types: fibroblasts, fibrocondrocytes, condrocytes and pyknosis (cell death). All randomly collected cell types were identified and counted for each sample. Histological plates were analyzed by computer image analysis system consisting of a Nikon FDX - 35 video camera coupled to a Nikon optic microscope (Eclipse 800), with multicolor objectives transmitting images to a Pentium MMX MHz PC with 64 megabytes of RAM, operating under Windows and equipped with digitizing board and ImagePro Plus software.

\section{Statistical analysis}

Significance level $0.05(\mathrm{a}=5 \%)$ was adopted in all statistical tests, and descriptive values (p) below this value were considered significant. Analysis of Variance (ANOVA) with one fixed factor was applied to the experiment at -7.2 ${ }^{0}$ Celsius to evaluate differences between freezing periods (in days) and the percentage of viable cells. Differences were located by Bonferroni's multiple comparisons tests. Analysis of Variance (ANOVA) with two fixed factors was applied to experiments at $-21.4^{\circ}$ Celsius and $-73^{\circ}$ Celsius aiming at comparing both temperatures and evaluate differences between freezing times (in days) and percentage of viable cells. Polynomial Regression Analysis was applied to experiments at $-21.4^{\circ} \mathrm{Celsius}$ and $-73^{\circ} \mathrm{Celsius}$ with best curve adjustment for percentage of viable cells as a function of freezing time as from 16 days.

\section{Results}

Quality of cells studied from the 2nd to the 6th day was not significantly different in morphology, what could be confirmed by readings from $2^{\text {nd }}$ (Figure 1$), 8^{\text {th }}$ (Figure 2 ) and $16^{\text {th }}$ day (Figure 3 ). However, from the $26^{\text {th }}$ to the $30^{\text {th }}$ day (Figures. 4 and 5), changes are highly evident. Qualitative cell analysis has not shown predominance of changes among different cell types, so results of cell viability are presented altogether (Figure 1). As from the $6^{\text {th }}$ observation day, curves presented behavior curves which were better evaluated by polynomial regression curves. Regression 
model was statistically significant ( $\mathrm{p}<0.001$ ) with $89.7 \%$ explanation coefficient for $-7.2^{\circ} \mathrm{C}$ (Figure 7 ), showing adequate adjustment; regression model was statistically significant $(\mathrm{p}<0.001)$ with $94.7 \%$ explanation coefficient for $-21.4^{\circ} \mathrm{C}$ (Figure 8), showing very good adjustment; and regression model was statistically significant $(\mathrm{p}<0.001)$ with $97.1 \%$ explanation coefficient for $-73^{\circ} \mathrm{C}$ (Figure 9), showing very good adjustment.

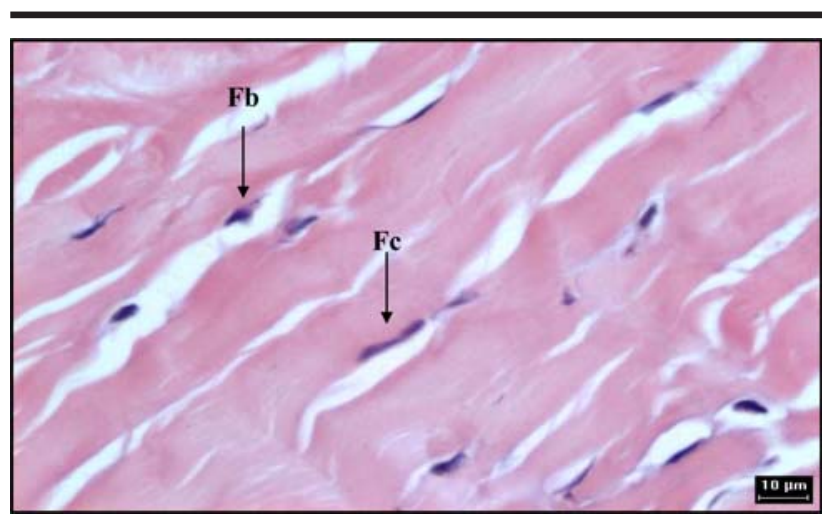

FIGURE 1 - Photomicrography representing cell viability in the $2^{\text {nd }}$ observation day at $-73^{\circ}$ Celsius. Note: FB = fibroblasts, Fc fibrocondrocytes $(\mathrm{HE}-40 \mathrm{X})$.

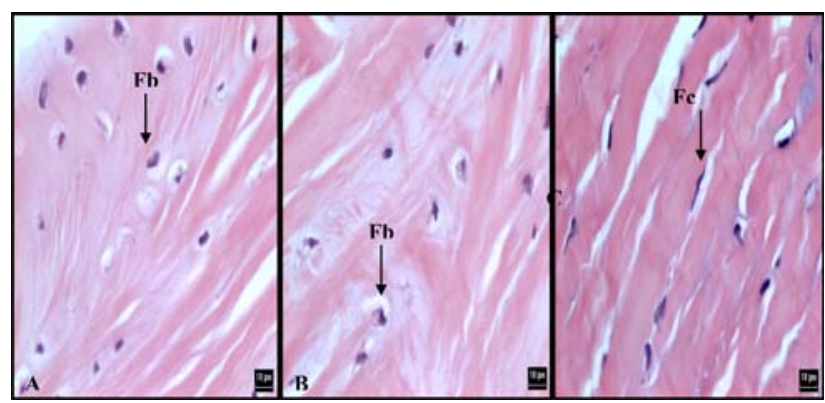

FIGURE 2 - Photomicrography representing cell viability in the $8^{\text {th }}$ observation day at $-7.2^{\circ}$ Celsius $(\mathrm{A})$, $21.4^{\circ}$ Celsius (B) and $-73^{\circ}$ Celsius (C). $\mathrm{Fb}=$ fibroblasts, $\mathrm{Fc}=$ fibrocondrocytes $(\mathrm{HE}-40 \mathrm{X})$.

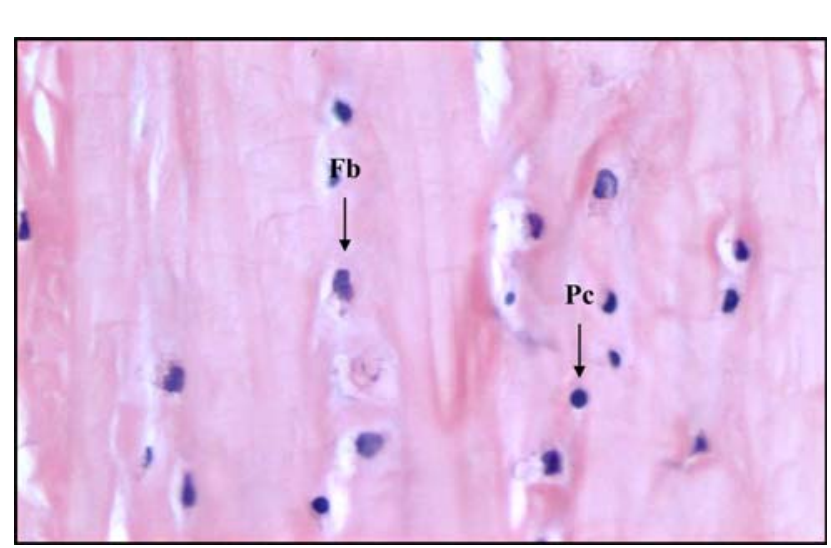

FIGURE 3 - Photomicrography representing cell viability in the $16^{\text {th }}$ observation day at $-73^{\circ}$ Celsius. $\mathrm{Fb}=$ fibroblasts, $\mathrm{Pc}_{\mathrm{C}}=$ pyknosis $(\mathrm{HE}-40 \mathrm{X})$.

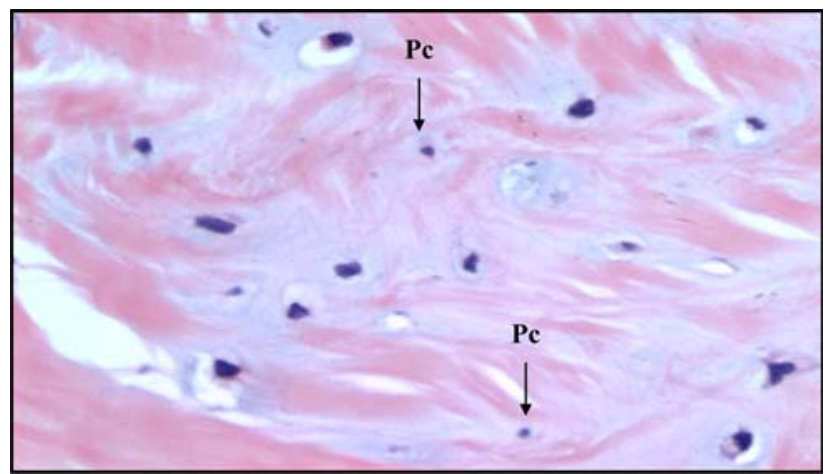

FIGURE 5 - Photomicrography representing cell viability in the $30^{\text {th }}$ observation day at $-73^{\circ}$ Celsius. Pc=pyknosis $(\mathrm{HE}-40 \mathrm{X})$.

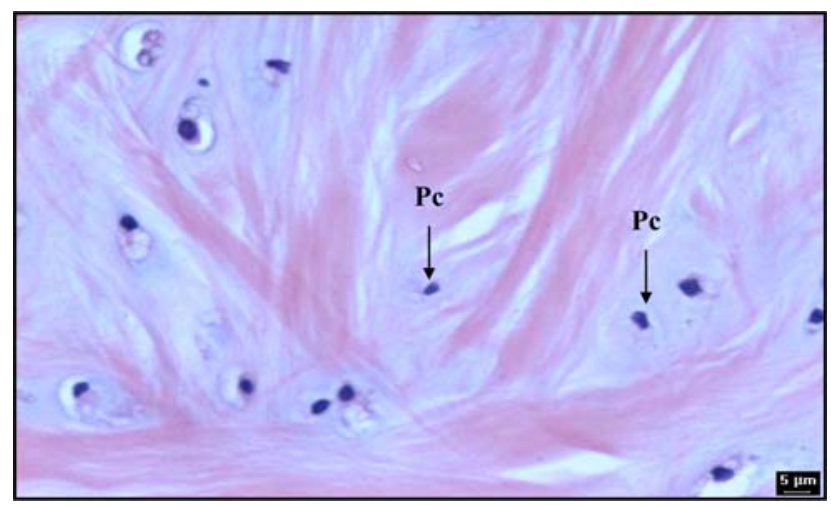

FIGURE 4 - Photomicrography representing cell viability in the $26^{\text {th }}$ observation day at $-73^{\circ}$ Celsius. Pc $=$ pyknosis (HE - 40X).

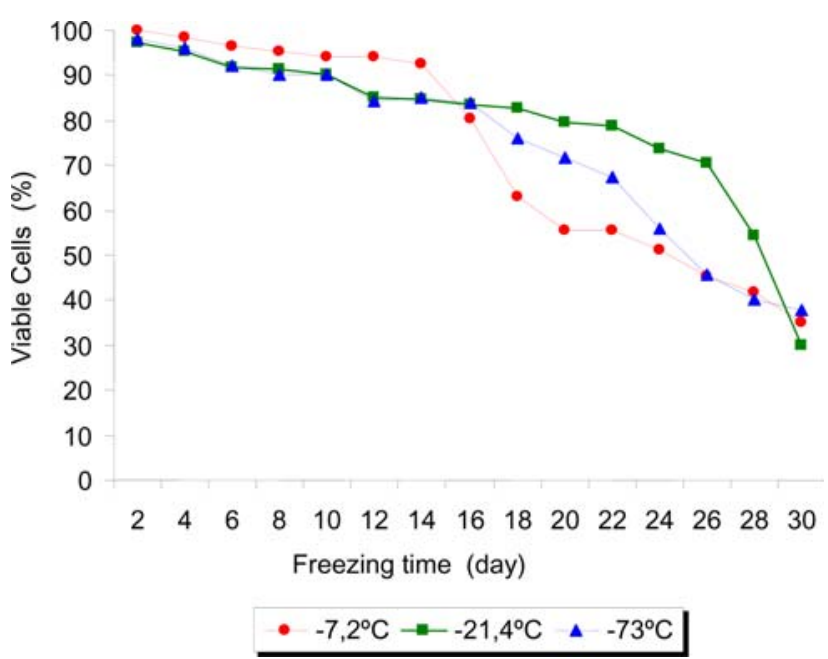

FIGURE 6 - Distribution of means and variations (standard deviation) of viable cells percentage in different freezing periods and fixed temperatures of 7. $2^{\circ}$ Celsius, $-21.4^{\circ}$ Celsius and $-73^{\circ}$ Celsius. 


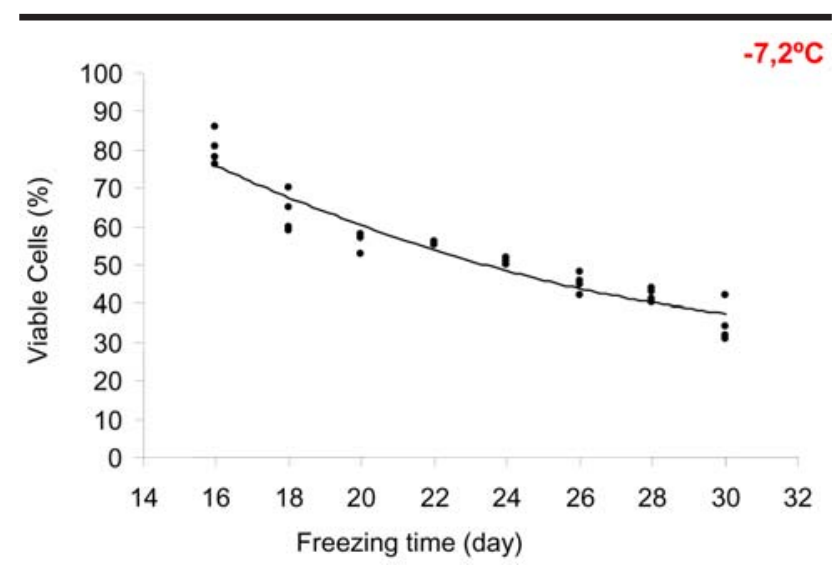

Legend: Viable cells $(\%)$, \% viable cells $=0.115 x$ day $2-8.055 x d a y$ +175.142 , Freezing time (day)

FIGURE 7 - Dispersion chart showing percentage of viable cells as a function of freezing at $-7.2^{\circ}$ Celsius.

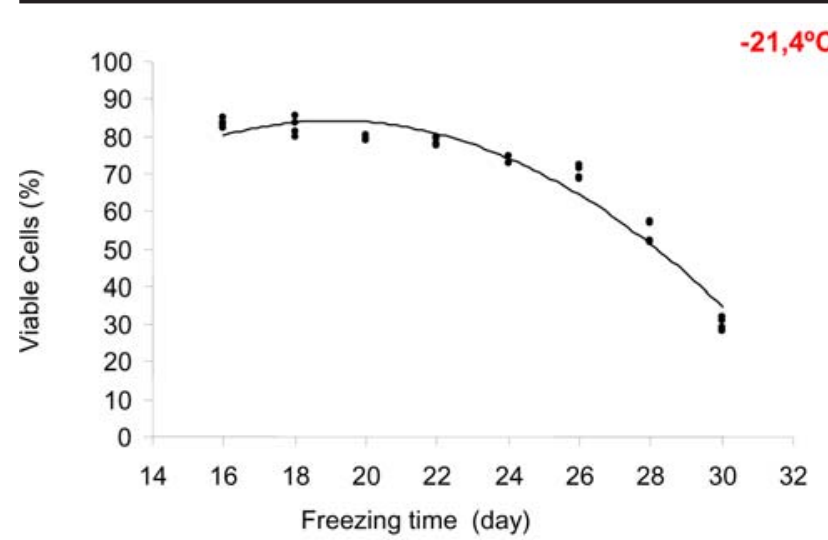

Legend: Viable cells (\%), \% viable cells $=0.415 x$ day2 $-15.846 x d a y$ +66.959 , Freezing time (day).

FIGURE 8 - Dispersion chart showing percentage of viable cells as a function of freezing at $-21.4^{\circ}$ Celsius.

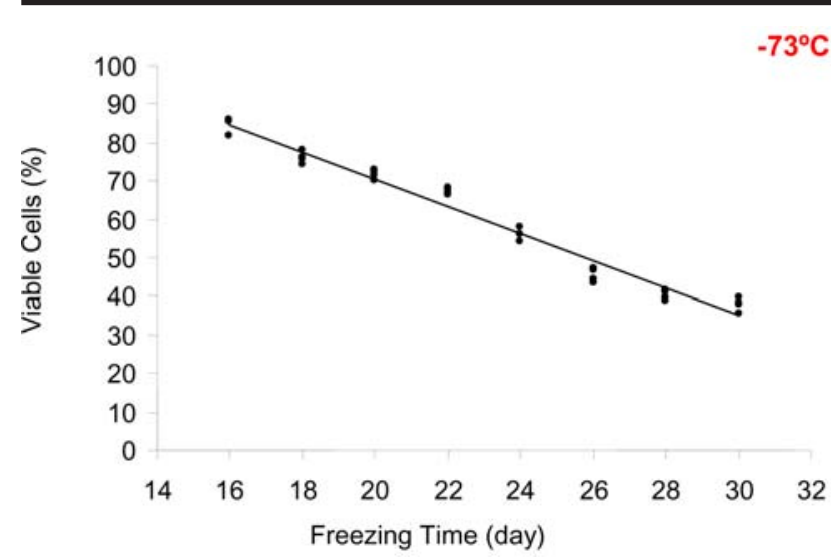

Legend: Viable cells (\%), \% viable cells $=3.511$ xday $2+140.580$ Freezing time (day).

FIGURE 9 - Dispersion chart showing percentage of viable cells as a function of freezing at $-73^{\circ} \mathrm{Celsius}$.

\section{Discussion}

Regardless of their origin, mechanism or extension, meniscal injuries are preferably treated aiming at restoring meniscus anatomic and functional integrity. Total or partial meniscus removal, when its restoration is unfeasible, is associated to joint degenerative processes which will invariably result in variable degrees of joint involvement ${ }^{10,12,13}$. So, the search for an alternative to this fibrocartilaginous tissue is still a challenge for orthopedic surgery. Homologous tissue replacement, that is, fibrocartilage of no beating donor or of multiple beating donors, has the advantage of using tissue morphologically similar to the tissue being replaced. Disadvantages are the possibility of the graft being a vector for infectious diseases and for tissue immune rejection processes ${ }^{14,15,16}$. The ideal would be a tissue which could maintain its physico-chemical profile and still be free from pathogenic agents. Simultaneously, this material would have to be prepared and stored for a reasonable period before being used. The fresh preservation method refers to menisci which, after removal, remain for 2 to 5 days at plus $4^{0} \mathrm{C}$, corresponding to typical home refrigerator temperature ${ }^{17,18,19,20}$. Limiting factor is the short period it is available for grafting. Deep freezing implies tissue storage and freezing at negative temperatures as from $0^{0}$ Celsius. It is a simple and widely used method to preserve menisci. In reviewing biomedical literature, it has been observed that there is no consensus and consistent basis for choosing the preservation method, especially in terms of temperature and meniscus cell viability. We decided then to investigate, in experimental animal model, the effects of three different temperatures in meniscal cells survival. Group I results show that up to 16 days, mean cell preservation varied from $99.83 \%$ to $80.38 \%$ and that as from the $18^{\text {th }}$ until the $30^{\text {th }}$ day, there has been a sharper decrease. Even so, there were mean $34.85 \%$ viable cells at the end of the period (Figure 6). This may show that authors advocating fresh meniscus transplantation may be offering, if the model is applied to humans, a high number of cells with antigenic potential to the receptor. Rejection does not seem to be a problem, since very few blood vessels and matrix density are unfavorable factors for immunerejection processes ${ }^{3}$. Groups II and III results show similar behavior until the $16^{\text {th }}$ day in mean viable cells as compared to freezing at minus 21.4 or minus $73^{\circ} \mathrm{C}$ (Figure 6). Figure 6 shows that curves with means and standard deviations are super imposable and may be analyzed as a single group. Based on this experimental model, this means that authors advocating freezing preservation may give up deep freezing (-73 ${ }^{0}$ Celsius) since lower freezing temperatures (-21.4 ${ }^{0}$ Celsius) lead to similar results. Figure 6 shows that mean viable cells has similarly decreased as compared to Group I, from the $2^{\text {nd }}$ to the $16^{\text {th }}$ day, varying from $97.63 \%$ to $83.68 \%$. This means that meniscal transplantation in any of the three studied temperatures carries a considerable population of donor cells until the $16^{\text {th }}$ day. As from the $18^{\text {th }}$ until the $30^{\text {th }}$ day, mean viable cells decrease was significantly higher in specimens submitted to deep freezing. Group II means were superimposed to Group I means, but were significantly lower as compared to Group III means. So, deep freezing provides lower viable cells means as compared to higher freezing temperatures. Notwithstanding this lower number of viable cells, they were still approximately $30 \%$ after 30 preservation days. Polynomial regression curves plotted as from collected data show this relationship in a clearer way (Figures. 7, 8 and 9). Cellularity decrease at the three temperatures until the $16^{\text {th }}$ day is similar. Variations as from the $18^{\text {th }}$ day are mild, however significant. Viability decrease in Group I is 
close to linear decrease, however significantly steeper as compared to Groups II and III. Decrease in Group III is linear, meaning a constant and equitable decrease day by day. In group III, this decrease is a second degree polynomial decrease, where there is constant viability decrease, but in lower numbers every day, with marked decrease only during the last observation days, when it is superimposed to levels observed for the other groups. Findings of this systematized cell viability study have no correspondence with any other study we could find in the literature. In general terms, this study allows us to conclude that, regardless of freezing method, cellularity decrease is similar until the $16^{\text {th }}$ day with approximately $80 \%$ of viable cells. From the $18^{\text {th }}$ to the $30^{\text {th }}$ day, cellularity decrease varies according to the freezing method, but all end up with approximately $30 \%$ of viable cells. In addition to quantifying by cell count (condrocytes, fibrocondrocytes, fibroblasts and pyknosis) it was possible to follow qualitative morphological changes of the preserved meniscus. From 2 to 16 days, there were no significant changes on cell organization and structural arrangement, and pyknosis rate was low. As from the $18^{\text {th }}$ day, changes became more evident with increased pyknosis and structural disarrangement of cell organization and composition. It was possible to identify tortuosity in fibrocondrocytes and fibroblasts organization, dissociation among cells filled by interstitial fluid or edema, and mild cell volume increase with loss of spindle shape. In summary, signs of cell necrosis by liquefaction have increased, leaving just the amorphous tissue corresponding to inorganic matrix. This study was just an evaluation to characterize remaining preserved menisci cells by hematoxylin eosin staining. This same material could be submitted to other methods, such as pricro-sirius red or polarization microscopy for collagen identification. Immune-histochemical methods may be used to identify and quantify inorganic matrix constituents. Research may continue investigating macroscopic and physico-chemical qualities of preserved menisci to evaluate tensile strength, deformation and breaking resistance. Matrix composition variation according to preservation period, measured by chondroitin-sulfuric acid or other elements is a feasible alternative to evaluate graft adequacy according to freezing methods. Apoptosis rate is also an alternative to evaluate the behavior of remaining cells to be transplanted to the donor. Remaining cells antigenic ability may be tested in "in vitro" or in animal models. Most attractive perspective is the study of preserved menisci to be submitted to homologous transplantation and evaluate graft repopulation. The continuity of this research line opens perspectives for systematic investigation of preserved grafts, not only menisci, but also other connective tissues.

\section{Conclusion}

The amount of viable meniscus cells is similar up to the $14^{\text {th }}$ day of preservation, under any of the used temperatures. However, from the $14^{\text {th }}$ day to the $30^{\text {th }}$ day, the amount of viable cells is smaller in lower temperatures.

\section{References}

1. Wirth CJ, Peters G, Milachowski KA, Weismeier KG, Kohn D. Long term results of meniscal allograft transplantation. Am J Sports Med. 2002;30(2):174-81.

2. Sekiya JK, Giffin R, Irrgang JJ, Fu FH, Harner CD. Clinical outcomes after combined meniscal allograft transplantation and anterior cruciate ligament reconstruction. Am J Sports Med. 2003;31(6):896-905.

3. Rijk PC. Meniscal allograft - part I: Background, results, graft selection, preservation, and surgical considerations. Arthroscopy. 2004;20(7):728-43.

4. Hamlet W, Liu SH, Yang R. Destruction of a cryopreserved meniscal allograft: a case for acute rejection. Arthroscopy. 1997;13:517-21.

5. Ellingson CI, Sekiya JK. Current opinion in meniscal allograft transplantation. Curr Opin Orthop. 2004;15(2):79-85.

6. Peters G, Wirth CJ. The current state of meniscal allograft transplantation and replacement. Knee. 2003;10:19-31.

7. Fabbriciani C, Lucania L, Milano G, Pannia AS, Evangelisti M. Meniscal allografts cryopreservation vs deep frozen technique. An experimental study in goats. Arthrocopy. 1997;5:124-34.

8. Friedman MD. Meniscal Allografts. Arthroscopy. 2003;18:33-9.

9. Tom JA, Rodeo SA. Soft tissue allografts for knee reconstruction in sports medicine. Clin Orthop. 2002;(402):135-56.

10. Vangsness CT, Garcia IA, Mills CR, Kainer MA, Roberts MR, Moore TM. Allograft transplantation in the knee: tissue regulation, procurement, processing, and sterilization. Am J Sports Med. 2003;31(3):474-81.

11. Debeer P, Decorte R, Bellemans J. DNA analysis of a transplanted cryopreserved meniscal allograft. Arthroscopy. 2000;16(1):71-5.

12. Graf Jr, KW, Sekiya JK, Wojtys EM. Long-term results after combined medial meniscal allograft transplantation and anterior cruciate ligament reconstruction: minimum 8,5 year follow-up study. Arthroscopy. 2004;20(2):129-40.

13. Felix NA, Paulos LE. Current status of meniscal transplantation. Knee. 2003;10:13-7.

14. Johnson LL, Feagin JR, JA. Autogenous tendon graft substitution for absent knee joint meniscus: a pilot study. Arthroscopy. 2000;16:191-6.

15. Sgaglione NA, Steadman R, Shafter B, Miller MD, Fu FH. Current concepts in meniscus surgery: resection to replacement. Arthroscopy. 2003;19(10):161-88.

16. Milachowski KA, Weismeier K, Wirth CJ. Homologous meniscus transplantation: Experimental and clinical results. Int Orthop. 1989;13:1-11.

17. Carter TR. Osteocondral allograft transplantation. Sports medicine and arthroscopy review 2004;11(4):264-71.

18. Rijk PC, van Noorden CJF. Structural analysis of meniscal allograft after immediate and delayed transplantation in rabbits. Arthroscopy. 2002;18:995-1001.

19. Ochi M, Ishida O, Daisaku H, Ikuda Y, Akiyama M. Immune response to fresh meniscal allografts in mice. J Surg Res. 1995;58:478-84.

20. Ball S, Amiel D, Williams S, Tontz W, Chen A, Sah R, Bugbee $\mathrm{W}$. The effects storage on fresh human osteochondral allografts. Clin Orthop Relat Res. 2004;1(418):246-52. 
Correspondence:

Leandro José Reckers

Rua Dr. Altino Arantes, 958/42

04042-004 São Paulo - SP Brazil

Phone: (5511)5599-4645

Fax: (5511)5571-0233

leandroreckers@uol.com.br
Conflict of interest: none Financial source: CAPES

Received: May 11, 2005

Review: June 14, 2005

Accepted: July 15, 2005

\section{How to cite this article:}

Reckers LJ, Fagundes DJ, Cohen M, Raymundo JLP, Moreira MB, Paiva VC. Effects of different preservation temperatures and periods menisci cellularity in rabbits. Acta Cir Bras. [serial on the Internet] 2005 Nov-Dec;20(6). Available from URL: http://www.scielo.br/acb

* Color figures available from www.scielo.br/acb

\section{Elaboração e Apresentação de Comunicação Científica}

\section{Saul Goldenberg}

\section{Carlos Alberto Guimarães}

\section{Aldemar Araujo Castro}

\section{Editores}

\section{Consulte: http://www.metodologia.org}

